\title{
WILLIAM HEBERDEN THE ELDER (1710-1801): ASPECTS OF HIS LONDON PRACTICE
}

\author{
by
}

\section{ERNEST HEBERDEN*}

Although William Heberden was one of the most distinguished clinicians of his day, no attempt has previously been made to bring together the available material, scattered in various published works and unpublished MSS, which could throw light on his London practice. I attempt in this article to find some answers to three groups of questions: first, what were the factors that Heberden had to weigh up before exchanging the security of his life in Cambridge for the hazards of private practice in the metropolis, and what special qualifications had he acquired that contributed to his success? Second, what did his patients (and others) have to say about his ministrations and about the more general problems of health and sickness? Finally, what does Heberden himself tell us about his attitude to his patients, and how was this attitude modulated by his views on contemporary theories and procedures?

Before calling our witnesses, we must summarize the facts about Heberden's background and the course of his career at Cambridge. Son of a Southwark innkeeper (who died when he was seven), he attended the parish grammar school of St Saviour-an Elizabethan foundation providing free education, heavily weighted on the side of the Classics, which might open doors for advancement in the learned professions to the brighter sons of the poor. With the backing of an imaginative headmaster and an exhibition worth $£ 7$ per annum, ${ }^{1}$ Heberden was admitted to St John's College, Cambridge, as a sizar at the age of fourteen. In 1731 (three years after obtaining his BA), he was elected Fellow of his college, ${ }^{2}$ and it was at this point that he began the study of medicine.

Owing to the deficiencies of the medical faculty, most of Heberden's studies seem to have been self-directed; he received his MD in $1738,{ }^{3}$ and two years later delivered the first of his annual series of public lectures on materia medica. In these, he demonstrated his wide reading of the literature (both ancient and modern) and-still more important-his ability to subject even the most venerated authors to searching criticism. ${ }^{4}$ If he enjoyed entertaining his audience by pricking the balloons of

\footnotetext{
*Ernest Heberden, 199 Lower Mortlake Road, Richmond, Surrey TW9 2LP.

${ }^{1}$ School Records, St Olave's and St Saviour's Grammar School Foundation, Orpington, Kent.

2 R. F. Scott (editor), Admissions to the College of St. John the Evangelist in the University of Cambridge, Cambridge, 1882.

${ }^{3}$ By a special dispensation of the Senate (see Grace Book for 27 April 1737 in the Cambridge University Library) Heberden received his MD one year earlier than the statutes normally permitted. The College Buttery Books refer to him as Doctor from August 1738 onwards.

${ }^{4}$ The MS of the introductory lecture is in the Francis A. Countway Library of Medicine, Boston, Mass.
} 


\section{Ernest Heberden}

superstition and deriding nonsensical theories, his arguments were all directed to the same conclusion: that the physician can never shrug off his personal responsibilties to his patients by blindly following "authority", but must always be guided by his own direct observations and his accumulating experience. A similar message can be found in the short work that he wrote for his students, "An introduction to the study of physic', 5 and the pamphlet entitled 'Antitheriaca', 6 in which he argued that the concoctions known as theriac and mithridatium did not deserve their place in the London Pharmacopoeia.

Apart from writing and lecturing, Heberden was beginning to make his name as an able and sympathetic practitioner, attending patients in the University, widening his experience at Scarborough ${ }^{7}$ during the long vacations, and making occasional trips to London, where he acted as an upaid assistant physician at St Bartholomew's Hospital. $^{8}$ In the course of these activities, he met several of the most influential physicians of the day, including the enormously wealthy Sir Richard Mead, ${ }^{9}$ Sir Edward Wilmot (a former student of St John's), and Sir Edward Hulse, royal physician during three reigns. It is no surprise that, with such backing, Heberden was soon elected (in 1746) Fellow of the Royal College of Physicians.

Besides his strictly professional concerns, he was actively interested in religion, literature, and science, and his "clubbable" personality attracted a wide circle of friends, many of whom were later to become his patrons and patients. Among the most prominent of these were Philip and Charles Yorke, sons of the Lord Chancellor, the Earl of Hardwicke. ${ }^{10}$

By 1748, Heberden knew that his opportunities for further advancement in the University were slender, particularly as the most enviable position-the Regius Professorship of Physic - had only recently been awarded to Dr Russell Plumptre. ${ }^{11}$ In July, an encouraging letter from Sir Edward Hulse ${ }^{12}$ urged him to set up practice in London. The moment was opportune and Heberden lost no time in coming to a decision; he arrived in London in October and by Christmas had settled into a house in Cecil Street, on the south side of the Strand.

Any physician contemplating a move to London in 1784 would have been aware that competition was keen. The capital was a magnet to the ambitious, and therapies were on offer not only from qualified physicians but from surgeons, apothecaries, unlicensed practitioners, midwives, bone-setters, wise-women, clergymen, and quacks. From Simmons's Medical Register of $1783,{ }^{13}$ it appears that there was one doctor (i.e. a

${ }^{5}$ The original MS is in the Francis A. Countway Library. A transcription of an inferior copy was published by Le Roy Crummer in Ann. med. Hist., 1928, 4: 349-367.

${ }^{6}$ Heberden, Antitheriaca or an essay on mithridatium etc., 1745.

7 BM Add. MS 32457, correspondence of Dr C. Middleton.

${ }^{8}$ See V. C. Medvei and John Thornton (editors), The Royal Hospital of St. Bartholomew 1123-1973, London, St Bartholomew's Hospital, 1974, p. 137.

${ }^{9}$ Mead (1673-1754) was FRCP and FRS; he had amassed an enormous collection of books and objets d'art, which Heberden was invited to view in 1741; see BM Add. MS 6269.

${ }^{10}$ Philip (1720-90) and Charles (1722-70) were at the centre of a literary circle to which Heberden belonged. All the members contributed to a volume entitled The Athenian letters.

11 Plumptre (1709-93) held the professorship until his death, but there is no evidence that he was active in teaching. However, he was well connected, and had an extensive private practice.

${ }_{12}$ See William Macmichael, The gold-headed cane, 2nd ed., London, 1828, pp. 169-173.

13 Samuel Foart Simmons (editor), Medical Register, London, 1783. 
physician, surgeon, or apothecary) per roughly 850 members of the population, and there is no reason to suppose that this proportion was substantially different a generation earlier.

In view of his past successes, his patrons, friends and connexions, Heberden had every reason to enter the competitive melée with confidence; but there was one other question to be resolved: had he enough money to acquire and furnish a suitable house and to maintain a reasonable standard of living while the practice was being established? At the outset of his career, his sole source of income was his Fellow's stipend.${ }^{14}$ Extra guineas began to flow in with the inauguration of his annual course of lectures, ${ }^{15}$ and during the next eight years, his income must have risen steadily as his name became more widely known and his list of patients increased. By living in his College, his day-to-day expenses were kept to a minimum and the opportunity to save for the future greatly enhanced. There are no records to tell us whether these savings were sufficient to cover the costs of the new enterprise or whether Heberden received some form of financial help from one of his wealthy patrons; at all events, he had soon managed to furnish, equip, and staff his bachelor establishment in a manner fit for the reception of his patients at consultations and of his friends at dinner-parties.

To discover his general attitude towards his professional responsibilities, we can turn to his Introduction to the study of physic (completed in 1741) where he expressed his distrust of general theories or systems of health and sickness on the grounds that their authors frequently produce "a medley of fact and fiction". Partly for this reason, he had a special admiration for Thomas Sydenham, ${ }^{16}$

\begin{abstract}
whose merit is, that he is an original [author] giving only what he himself observed of diseases; and in doing this is judged to have come nearer to the true Idea of a practical writer than most other authors; as he has mixed but little of hypothesis \& speculation with what he says, being generally contented with relating an exact history of the rise \& progress of the disease, \& of that method of treating the patient, which was found most effectual in conducting him easily to a speedy recovery.
\end{abstract}

For a general working theory (however inadequate in many cases) Heberden favoured the humoral doctrine, and confirmed this in the second chapter of the Commentaries $^{17}$ 'Ratio Medendi' thus:
One of the first considerations in the cure of a disease is, whether it require any evacuations; that is, whether it have been the general opinion of practical authors, that emetics, cathartics, diuretics, bleeding (by leeches, cupping-glasses, or the lancet), sudorifics, blisters, issues, sternutatories, or salivation, have in similar cases been found to be beneficial.

These extracts, and others quoted below help to define Heberden's attitude to his patients; records of the patients' views (or those of gossiping third parties) are

\footnotetext{
${ }^{14}$ Worth approximately $£ 41$ p.a. (St John's College archives).

${ }^{15}$ Heberden charged 2 guineas for the course (see handbill in St. John's College library).

${ }^{16}$ Sydenham (1624-89) fought as a young man in Cromwell's army and then turned to medicine. Shortly after the Restoration, he began a clinical study of London epidemics, for which he was inclined to accept the corpuscular theory as an explanation. He had little faith in academic science, but as an observer of the signs and symptoms of disease, he was without rival. See Kenneth Dewhurst, $\operatorname{Dr}$ Thomas Sydenham (1624-89). His life and original writings, London, Wellcome Institute for the History of Medicine, 1966.

${ }_{17}$ William Heberden, Commentaries on the history and cure of disease, London, T. Payne, 1802 (hereinafter referred to as Commentaries).
} 
regrettably sparse, but they are at least sufficient to give an outline of some features of the current medical scene as viewed from the more prosperous end of the market.

We owe our first extract to the common habit of seeking medical advice by post. Heberden's correspondent was the unorthodox cleric and controversial author, Conyers Middleton, who had been a close friend for some twelve years. Middleton, who had recently married for the third time, had one house in Cambridge and another, to which he retired in the summer, at the neighbouring village of Hildersham. Early in 1750, he wrote:

\begin{abstract}
My wife has for sometime past been free from that sort of complaint which she had in London but has long been troubled with an ugly dry cough attended with a constant uneasiness in her breast which gives her pain as oft almost as she draws her breath. I advise her to bleed for it, but she waits for proper weather to take the benefit of the air \& gentle exercise which she has wholly omitted; \& scarce stirred out of the house since we came last from Hildersham; for domestic cares have much confined \& disturbed us of late; two servants taken with the small pox, one of whom died lately in the house; a maid fresh from Hildersham, \& sister to the two whom you formerly cured with us; the other our coachman, who for several days past has been given over, but is struggling still for life at a Nurse's house, whither we sent him ....

That I am opening to you all our grievances, both of mind \& body; as to a common physician of both: but insure onely the health of my wife and the rest we will take care of ourselves .... ${ }^{18}$
\end{abstract}

Middleton's account of his wife's cough is clear and succinct and his readiness to prescribe treatment neatly illustrates the feeling commonly held by educated laymen that as far as the more familiar ailments were conerned, they knew almost as much as their physicians. No doubt this attitude was sometimes justified; in any case, a gentleman grounded in the Classics would have found nothing esoteric in medical jargon and would probably have felt more competent than his counterpart today to discuss symptoms and treatment with his physician on an equal footing. Middleton's knowledge of medical matters would have been bolstered by the abundance of information readily available to laymen at all literate levels of society: self-help books to guide one through the perils of illness and injury; books on how to avoid illness by observing rules of health and a sound "regimen"; and regular advertisements in the newspapers extolling the virtues of patent remedies. Perhaps the most respectable and respected source of advice for the educated reader such as Middleton were the articles of medical interest that appeared each month in the Gentleman's Magazine, ${ }^{19}$ which later summarized several of Heberden's contributions to the Medical Transactions of the Royal College of Physicians (see below).

Middleton's reference to the two maids "formerly cured" clearly indicates that Heberden was prepared to treat all the members of a household, including the servants and retainers. Although we have no positive evidence that this was a regular feature of Heberden's London practice, it would certainly have made sense for a gentleman of means with a large establishment to try and insure against the inconvenience of sickness among his staff by paying the family physician to care for them.

Middleton's wife duly recovered, but he was soon in trouble himself, and in July, Horace Walpole wrote: "Dr. Middleton called on me yesterday: he is come to town to

18 BM Add. MS 32457.

19 Roy Porter, 'Lay medical knowledge in the eighteenth century: the evidence of the Gentleman's Magazine', Med. Hist., 1985, 29: 138-168. 
consult his physician for a jaundice and swelled legs, symptoms which the doctor tells him, and which he believes, can be easily cured; I think him visibly broke, and near his end." 20 Walpole's prognosis was correct, but if Heberden was equally aware of his friend's condition, he can hardly be faulted for withholding the truth, which might well have added to his patient's distress. When Middleton died a few days later, $\mathrm{Dr}$ Plumptre was at his bedside and wrote at once to Heberden:

\begin{abstract}
[Middleton] talked a little while with me ... he told me he had designed to write to you, but feared he was too weak to do it: I asked him if I could write for him, he thanked me \& said he should be obliged to me if I would; the sum of what he said was as near as I can remember to this effect: that he had left off taking his medicines as they were disagreeable to him \& because he was fully sensible that his case was such as would admit of no remedy, that he was resigned \& even desirous of dying \& therefore you must excuse him if he took nothing more ....21
\end{abstract}

Most of Heberden's advice was delivered in the presence of his patients or their attendants and on these occasions the need for written communications (apart from prescriptions) did not arise; but of his former patients at Cambridge, we can be sure that Middleton was not the only one to ask for and receive advice by post, and as travel was so time-consuming, letters could often be a satisfactory substitute for personal attendance even if patient and physician were no more than a few miles apart.

One of Heberden's many clerical friends was the Rev. Philip Morant (1700-70), writer and antiquarian, who had written a history of Essex and held several livings in and around Colchester. Late in 1750, his wife suffered a haemorrhage, and Heberden sent him a note informing him that "the bleeding will easily be kept in order and will have no bad consequences." A prescription was enclosed, together with a warning: "not scorbutic-not to be stopped by violent means. Godfrey's cordial together with all other opiate medicines, must be avoided." 22 We can draw two conclusions from the warning: Mrs Morant, like many of her contemporaries, might have been tempted to try some form of self-treatment, and although we cannot be sure what Heberden had in mind when using the words "violent means", they certainly implied danger.

By now, Heberden's contacts had been widened by his election to Fellowship of the Royal Society, and in 1752, his financial position and social status were both enhanced by his marriage to a daughter of John Martin, banker and Member of Parliament. About the same time, he was introduced to his future patient, the tireless correspondent Mrs Delany, who enjoyed the favour of the royal family and was known to everyone at court. We owe to her one of the few direct observations by a patient of Heberden's personality, written late in 1754 , when he had lost his wife shortly after the birth of their son: "I am sure you are much concerned for Dr. Heberden on the death of his wife; his gentle and affectionate disposition will make him for some time very miserable." 23 The best way to recover his natural buoyancy was to keep himself fully occupied - a view evidently held by Mrs Delany, who made no further reference to his loss and within a month described his attendance on the schoolboy son of the Duchess

\footnotetext{
${ }^{20}$ Peter Cunningham (editor), Horace Walpole's letters, London, 1857-59, letter 308.

21 BM Add. MS 32457.

22 BM Add. MS 37222 f66.

${ }^{23}$ Lady Llanover (editor), Life and correspondence of Mrs Delany, 6 vols., London, 1862, vol. 3, p. 308. Mary Delany was the widow of Dr Patrick Delany, scholar and preacher, who had been a close friend of Dean Swift.
} 


\title{
Ernest Heberden
}

of Portland at her Buckinghamshire mansion, Bulstrode Park, some eight miles to the north of Windsor:

\begin{abstract}
The next morning Lord Edward complained of excessive weariness, and had no appetite; at night the Duchess ordered him some Gascoign's powder and small negus, but it would not stay on his stomach; he fell asleep and the next morning was a little feverish, the apothecary sat up with him. Doctor Hays from Windsor was sent for, and all symptoms made them suspect it would prove the small-pox. We were yesterday greatly alarmed; the child was excessively ill, Dr. Heberden is here; he finds the child in as good a way as can be expected in the beginning of such a disorder, for it proves the small-pox. The doctor seems to think it will be a middling sort, neither the best nor the worst. ${ }^{24}$
\end{abstract}

Gascoign's powder was one among hundreds of patent medicines to which the inventors had given their names. It is not surprising that the duchess was prepared to prescribe the powder, without waiting for advice, and her employment of the apothecary as a nurse reminds us that these very important members of the medical fraternity were not limited to their primary function of pharmacy. ${ }^{25}$ As for Heberden's assessment of the severity of the boy's illness, he classified each case of smallpox as mild, middling, or severe in the light of the early symptoms. ${ }^{26}$ On this occasion (as on many others), more than one doctor was called in. There is no evidence that this caused resentment; it was generally accepted that the powers of even the most respected physicians were very limited, that many illnesses were dangerous, and that the effects of any course of treatment were uncertain. The common thing, if one could afford it, was to take at least two opinions from the best qualified physicians within reach. From the physician's viewpoint, this was an entirely satisfactory arrangement: he got his fee, while sharing the load of responsibility.

The notion that wealthy and influential patients always "called the tune" can be accepted only with reservations; everything depended on the degree of trust and respect with which they viewed the physician of their choice. Thus, Mrs Delany was prepared on at least one occasion to accept Heberden's instructions at the cost of some personal inconvenience: ". . . I hope it will not be thought necessary for me to go to Cheltenham till the middle of August. I pleaded hard for drinking the waters at home, but Dr. Heberden will not hear of it." 27

Heberden frequently advised his wealthy patients to make a visit to a spapreferably to Bath, where the accommodation and surroundings were considered most agreeable. His attitude to the alleged medicinal virtues of spa water was somewhat ambivalent; but the most important factor in a visit to a spa was the change of routine and the respite from work, domestic worries, or over-indulgence.

Heberden had begun to hold dinner-parties for his literary and scientific friends very soon after arriving in Cecil Street. ${ }^{28}$ Some of his guests were also his patients, and among these was the printer-turned-novelist, Samuel Richardson, who suffered from a nervous disorder which sometimes made it hard for him to hold a pen. Early in 1751, a

${ }^{24}$ Ibid., pp. 313-314.

${ }^{25}$ See Juanita G. L. Burnby, A study of the English apothecary from 1660 to 1760 , London, Wellcome Institute for the History of Medicine, 1983.

${ }^{26}$ See Commentaries, ch. 95.

${ }^{27}$ Llanover, op. cit., note 23 above, p.357.

28 J. G. Nichols, Illustrations of the literary history of the eighteenth century, 7 vols., London, 1817-58, vol. 2, p. 147. 
correspondent, having enquired after Richardson's health, ended his letter: "But I must dismiss you or I shall bring Dr. Heberden upon my Back. Yet he does not say that you must not read letters? No-but he will say that I write with a wicked Design to provoke you to write again." ${ }^{29}$ If Heberden had advised his patient to write less, this was certainly a difficult injunction for any author to follow. Three years later, Richardson wrote to a friend: “. . . Good Doctor Heberden has made me within a week two friendly visits; and yesterday [Friday] I had the pleasure of dining with him and six other learned gentlemen at his house by particular invitation." ${ }^{30}$ When he was again unwell in August 1757, he wrote: "I have left off Physic. Good Dr Heberden ... told me that I must not expect relief from it. And I am got deep into Tar-Water. Three or four times a day, by Entreaty of an experienced, tho' not medical Friend."31 It is not entirely clear whether the "Physic" had been prescribed by Heberden, who later saw that it was doing no good, or had been taken without his authority. As for the tar-water, experiments in self-medication were so common that it is unlikely that Heberden was either surprised or offended by his patient's action in relying on it; he continued to visit him, and when Richardson died of a stroke in 1761, he left Heberden a ring as a token of their friendship. ${ }^{32}$

Another literary patient was the poet William Cowper, who had studied law and had rooms in the Inner Temple. He suffered from bouts of depression and in 1763 made several attempts at suicide. In his Memoir of his early life he wrote: "I saw plainly that God alone could deliver me; but was firmly persuaded that he would not, and therefore omitted to ask it. Ask it indeed at his hands, I would not, but as Saul sought to the witch, so did I to the physician Dr. Heberden; and was as diligent in the use of drugs, as if they would have healed my wounded spirit, or have made the rough places plain before me." ${ }^{33}$ From this passage alone it would be hard to judge whether Cowper considered Heberden's form of therapy effective or not; certainly the drugs seem to have failed in their purpose. But twenty years later, in his poem Retirement, the poet paid his physician a handsome tribute:

\footnotetext{
Virtuous and faithful HEBERDEN, whose skill Attempts no task it cannot well fulfil, Gives Melancholy up to nature's care, And sends the patient into purer air.
}

Even allowing for some poetic licence, these lines make it clear that Heberden relied mainly on the recuperative powers of nature, and that he helped the process along by sending the patient away from the scene of his breakdown, to benefit by a change of surroundings in the country. Cowper, in fact, went to Margate during the summer-a trip probably taken on Heberden's advice. As Heberden was a devout (but extremely practical) Christian, he may have tried to restore the poet's religious faith as a means of overcoming his feelings of hopelessness. If this theory is correct, it would give point to the words "virtuous" and "faithful".

\footnotetext{
${ }^{29}$ T. C. D. Eaves and B. D. Kimpel, Samuel Richardson, a biography, Oxford University Press, 1971,

${ }^{30}$ John Carroll (editor), Selected letters of Samuel Richardson, Oxford, Clarendon Press, 1964.

31 Eaves and Kimpel, op. cit., note 29 above, p. 514.

32 Ibid., p. 517

${ }^{33}$ Memoir of the early life of William Cowper, 2nd ed., London, 1816, p. 40.
} p. 322 . 


\section{Ernest Heberden}

One of Heberden's many Cambridge friends was the Rev. Richard Hurd. ${ }^{34}$ Writing to a clerical colleague, the Rev. Thomas Balguy, Archdeacon of Winchester, in March 1735, he referred to the occasion - the only one recorded - when Heberden himself was unwell: “... I have the pleasure to inform you that Dr. Heberden is quite recovered from his late illness, which, to the disgrace of temperance, ended in a fit of the gout. Besides its other ravages, it has stripped the doctor of a good deal of that flesh, with which, as you know, his bones were so unmercifully encumbered." 35 Whatever the nature of the malady, we know that Heberden was normally "thin and spare";,36 evidently, the trouble began with a swelling of the limbs, which later subsided during the other unspecified "ravages".

Twenty years later, Hurd (now himself unwell) wrote again to Balguy; his warm commendation of Heberden's qualities as a physician was counterbalanced by his strong disapproval of Heberden's active involvement on the side of the Dissenters in the campaign to exempt them from certain Penal Laws in $1772:{ }^{37}$

... But apropos to my bilious cholic. The news of it flew to Dr. Heberden, who very humanely came to me this morning. As soon as he had heard my history, and prescribed as he thought fit, he passed immediately, and with high approbation, to the mention of that note to your Charge which gives up the cause of the Bishops to the petitioning Dissenters .... Is it not much to be lamented, that so excellent a man, who might claim respect of all the world in his own department, will strive in another province, where, at most, he can but merit our pardon on the score of his good intentions? ? $^{38}$

Heberden would have strongly denied that he was stepping outside his "province"; the controversy concerned laymen as much as clerics, and was not entirely irrelevant to the medical scene, in view of the exclusion of dissenting physicians from the English universities.

In October 1765, Heberden wrote to his old Cambridge friend Philip Yorke (by now Earl of Hardwicke) concerning the health of the Earl's younger daughter, Lady Mary Jemima:

My Lord, As I know nothing of Lady Mary's disorder but from one conversation with Sir W. Duncan, ${ }^{39} \mathrm{I}$ can hardly imagine that I have anything to say about it more than your Lordsp. must have already heard. As far as I am able to judge, nothing has yet happened to make us despair that her health may be perfectly restored. But if I had been longer acquainted with the case, it is such an one which so seldom happens, that I am sensible it would not be in my power to judge with certainty of the event. When Lady Mary returns to town, I shall be ready to wait upon her Ladyship, as soon as I receive your commands. I am, my Lord, your Lordship's most humble servant W. Heberden Cecil St. ${ }^{40}$

In spite of the courteous tone of the letter, Heberden barely disguised his feelings of

${ }^{34}$ Hurd (1720-1808) became Bishop of Worcester; he wrote on classical and theological subjects.

${ }^{35} \mathrm{~F}$. Kilvert, Memoirs of the life and writings of Richard Hurd, London, 1860, p. 48.

${ }^{36}$ The description given by Heberden's Cambridge contemporary, William Cole, in his Athenae Cantabridgienses, BM Add. MS 5871.

${ }^{37}$ The affair is described in Horace Walpole, Journal of the reign of King George the Third from 1771-1783, London, 1910, pp. 89-91.

${ }^{38}$ Kilvert, op. cit., note 35 above, p. 113.

${ }^{39}$ Sir William Duncan was MD of St Andrews and a Licentiate of the RCP; he was physician-in-ordinary to George III, and was created Baronet in 1764.

${ }^{40}$ BM Add. MS 35607 f200. 
impatience at being asked for advice without being given enough information on which to form a judgement.

Not long afterwards Heberden wrote once again to the Rev. Morant:

Cecil St May 16. 1767

Sir, I am extremely concerned that a sudden call out of town hindered me from seeing you on Thursday. But your case appears so clear to me that I think you could not have given a better account of it if I had seen you, than you gave in your letter. The Bark is in my judgement the proper remedy for your disorder and if you will be pleased to take half a quarter of an ounce every three hours for $\mathbf{2 4}$ hours and then four times a day for a week, you are not likely to have it return any more. Nothing need be added to the Bark and it may be taken in a glass of water alone or of milk and water. If after the fever is cured, the faintings should continue, be pleased to acquaint me with it and I shall with great pleasure endeavor to find out the proper means of removing them. I am $\operatorname{Sir} . .$. W. Heberden ${ }^{41}$

The letter illustrates the crucial importance of the patient's own description of his condition; Morant's account of his symptoms had evidently been so clear and comprehensive as to answer all the questions that a physician could possibly ask. As Peruvian bark was widely used in the control of fevers, it would have been readily available.

After a further gap of ten years, we have a letter to a medical colleague, Dr Cuming, ${ }^{42}$ concerning one of Heberden's patients, who had gone to Blandford in Dorset to convalesce after some unspecified illness:

Pall Mall 14 June 1777

Dear Sir, I am much concerned to find that Mrs. Frampton has not yet begun to recover her strength so fast as we wish. Bitters \& gentle evacuants, which you are using, appear to me the best means for the re-establishment of her health \& I own I should have a better opinion of their success, when taken under your care $\&$ direction, than from any effects which I can promise from Bath water. There would surely be a great disadvantage in Mrs. F's going from you, who have seen the whole progress of the illness, to a Physician who is a stranger to the case, \& may not immediately see the nature of it, $\&$ find out what the present state of her bowels may require $\&$ bear. This seems the principle reason against a Bath journey; for otherwise she might give herself the chance of what those waters could do in her case, $\&$ if they should be inefficacious, she might still take medicines at Bath with the same benefit as at her own house. Ass's milk in a morning, if Mrs. F. can bear it, may help to nourish her \& dispose her bowels to do their duty with the help of clysters only, or of such a small dose of Rhubarb, as would be unlikely to do too much. The bitters which you have found to agree with her may be taken at noon $\&$ at night; and, if it be judged necessary, elixir of vitriol may be added to them, as far as I can judge, with perfect safety.

Be pleased to present my compliments to Mr \& Mrs Frampton. I am, Dear Sir, Your most humble servant

W. Heberden ${ }^{43}$

Here we see the two physicians in complete agreement on a course of treatment that would have been prescribed with minor variations for many convalescents. Heberden's reservations about the efficacy of spa waters have been mentioned already. Had Mrs. Frampton gone to Bath and put herself under the care of another physician, it would presumably have been a simple matter for Cuming to write to him, describing the case

41 BM Add. MS 37222 f192.

42 William Cuming was a lifelong friend of the distinguished Quaker physician John Fothergill, whom he had first met in Edinburgh, when a medical student. He took his MD at Rheims and after returning to England in 1739, settled in Dorchester.

${ }^{43}$ MS in library of RCP, London. 


\section{Ernest Heberden}

and the current treatment. The chief disadvantage was the risk that the strange doctor might prove to be inferior in professional expertise and might see fit to alter the course of treatment.

A patient of a very different stamp was Philip Thicknesse, traveller, soldier, writer, and confident amateur physician. In 1780 , he revealed that he had for many years suffered from gallstones:

The last violent fit I had was ten or twelve years ago, when I passed the largest, and as Dr. Heberden then assured me, the only one that was in the gall bladder, and which is now in his possession; he knew it to be the only one, because it was not (like the others I passed) burnished in any part, as it would have been had other gall stones lay in contact with it .... Dr. H indeed is of the opinion that it is the most acute pain the human frame is liable to, and says that he has often seen it occasion a temporary madness ....4

Presumably, Thicknesse recorded this incident because he was impressed by Heberden's powers of observation and analysis. When, in 1788, he published his memoirs (to which Heberden subscribed), he remarked, a propos of $A$ treatise on biliary concretions (London, 1757) by Dr Thomas Coe of Chelmsford: "Dr. Heberden has highly commended Dr. Coe's book, and if I mistake not, has acknowledged himself instructed by it." The remark was probably true; certainly Heberden was an avid reader of medical literature, and it was largely due to his influence that the Medical Transactions of the Royal College of Physicians were inaugurated.

Several of the papers that he contributed to the first three volumes of the Transactions gained a wider readership by being summarized in the Gentleman's Magazine. ${ }^{45}$ Under the general heading "Queries", Heberden had dealt with controversial issues by inviting the reader to consider whether a particular item of received wisdom was confirmed by experience; for example, he argued against the theory that wet rooms, damp clothes, and beds are extremely dangerous. After giving a fairly lengthy summary, the contributor to the Gentleman's Magazine ventured some comments of his own, and although his tone was respectful, it is clear that he found some of the arguments hard to swallow. It is to this "Query" that Horace Walpole referred in the following letter to the Rev. William Cole, ${ }^{46}$ who was living in a small house at Milton, near Cambridge:

I am extremely concerned, dear Sir, to hear you have been so long confined by the gout. The painting of your house may, from the damp, have given you cold-I don't conceive that paint can affect one otherwise, if it does not make one sick, as it does me of all things. Dr. Heberden (as every Physician, to make himself talked of, will set up some new hypothesis,) pretends that a damp house, and even damp sheets, which have ever been reckoned fatal, are wholesome: to prove his faith he went into his own new house totally unaired, and survived it. At Malvern, they certainly put patients into sheets just dipped in the spring - however, I am glad you have a better proof that dampness is not mortal, and it is better to be too cautious than too rash. ${ }^{47}$

Walpole was not alone in his distrust of doctors, and Fanny Burney quoted from the conversation of her party guests an unflattering opinion of the medical profession in general and Heberden in particular:

44 Thicknesse, Valetudinarian's guide to Bath, Bath, 1780, p. 25.

45 For example, his paper 'Some account of a disorder of the breast' (Med. Trans., 1772, 2: 59) appears in Gentleman's Mag.,1772, p. 280; several of the queries (see below) are in ibid., 1773, p. 32.

${ }^{46}$ Walpole had been Cole's principal friend and companion during their schooldays at Eton; later they travelled together in France.

${ }^{47}$ Cunningham, op. cit., note 20 above, letter 1506. 


\section{William Heberden the elder (1710-1801)}

Mr Hamilton, who had now given his place at the whist-table to Mr. Bateson, related to us a very extraordinary cure performed by a physician, who would not write his prescriptions, 'Because', said he, 'they would not appear against him, as his advice was out of rule; but the cure was performed, and I much honour, and would willingly employ such a man'.

'How!' exclaimed Mr B-y, who always fires at the very name of a physician, 'what! let one of those fellows try his experiments upon you? For my part, I'll never employ one again as long as I live! I've suffered too much by them; lost me five years of the happiness of my life-ever since the year-let's see, ' 71,72 .... One of those Dr. Gallipots, now-Heberden attended a poor fellow I knew. 'Oh,' says he, 'he'll do vastly well!' and so and so on, and all that kind of thing: but the next morning, when he called, the poor gentleman was dead! There's your Mr. Heberden for you! Oh, fie! fie! fie! ${ }^{48}$

Physicians would naturally try to avoid upsetting their patients with gloomy and distressful prognoses and, as accurate diagnosis was often difficult or impossible, some show of optimism was excusable. But if the patient died and the survivors knew that the diagnosis had been faulty, the physician's reputation could be dented. The artist Thomas Gainsborough (Heberden's next-door neighbour in Pall Mall) died in 1788, and six years later his nephew described how he had caught a cold which caused a tumour to inflame; Gainsborough then "applied to Dr. Heberden who treated it lightly, and said it would pass away with the cold. He applied to John Hunter who advised salt water poultices which greatly increased the inflammation \& a suppuration followed. There seems to have been a strange mistake or neglect both in Heberden \& Hunter." 49

The case of the Rev. Dr Michael Lort, in his younger days librarian to Richard Mead and later Regius Professor of Greek at Cambridge, had a happier outcome. Early in 1781, the Rev. William Cole wrote to Walpole that Lort had been extremely ill, "but is got well again through the care of Dr. Heberden". ${ }^{50}$

Boswell mentioned Heberden for the first time in connexion with Topham Beauclerk, an original member of Johnson's Club: "21 March [1775]: Johnson informed me that though Mr. Beauclerk was in great pain, it was hoped he was not in danger, and that he now wished to consult Dr. Heberden to try the effect of a new understanding." 51

Although Johnson did not himself become Heberden's patient until 1783, he had already recommended him to others, including the Rev. John Taylor who lived in Derbyshire but visited London regularly. ${ }^{52}$ In a letter advising his friend to take care of himself, Johnson wrote: "Heberden's talk was rather prudential than medical: you might however perceive from it how much he thought peace of mind necessary to your re-establishment." 53 Johnson's comment points to an aspect of Heberden's talk which must often have been far more useful to patients (if they listened to it) than doses of

\footnotetext{
${ }^{48}$ Charlotte Barrett (editor), The diary and letters of the Countess D'Arblay (Fanny Burney) 1778-1840, with notes by Austin Dobson, 6 vols., London, 1904-5, vol. 1, p. 310.

${ }^{49}$ Kenneth Garlick and Angus Macintrye (editors), The diary of Joseph Farington, New Haven, Conn., Yale University Press, 1978-, vol. 1, p. 256.

${ }^{50}$ W. S. Lewis et al., The correspondence of Horace Walpole, London, Oxford University Press, 1937-83, vol. 2, p. 264.

51 James Boswell, Life of Samuel Johnson, London, Oxford University Press, 1935, p. 589.

52 Taylor was Vicar of Ashbourne in Derbyshire, but also had duties in London as Prebendary of Westminster Abbey.

${ }_{53}$ R. W. Chapman (editor), The letters of Samuel Johnson, Oxford University Press, 1952, letter 605.1.
} 
physic. Clear and coherent advice on "how to look after yourself" would on many occasions have speeded a recovery or prevented a condition from deteriorating; and although Heberden trod the path of tradition whenever he prescribed such routine measures as bleeding or clysters, he regarded them merely as means of encouraging the vis medicatrix naturae in which he so firmly believed.

When in June 1779, his friend and benefactor, the wealthy brewer Henry Thrale, had a stroke, Johnson was staying in the country. On receiving one of Mrs Thrale's letters giving him news of her husband's progress, he replied: “... I am glad that you have Heberden and hope his restoratives and his preservatives will both be effectual." 54 Four months later, when the patient appeared to be on the road to recovery and had been persuaded to make a trip to Tunbridge Wells, Johnson wrote: "I earnestly wish that before you set out, even though you should lose a day, you would go together to Heberden and see what advice he will give you ... I wish you would do yet more and propose to Heberden a consultation with some other of the Doctors." 55

Meanwhile, Mrs Thrale was confiding her private thoughts to her journal:

This Fryday 11: June $1779 \ldots$ Mr Thrale suddenly struck with the palsy as he sate at Dinner . . . last Tuesday . . . he has mended ever since the Attack; thanks to Bromfield ${ }^{56}$ who first administered Relief, \& afterwards called in both Huck ${ }^{57}$ \& Heberden.

22: June. Mr Thrale has recovered his paralytick Stroke: Doctor Heberden thinks him now wholly out of Danger as so much Time has elapsed \& the Attack has not been renewed.

1: Aug ... Heberden it seems told Seward ${ }^{58}$ privately that he would never wholly recover ....

Wednesday 24: Nov. We are come home from Brighthelmstone: on Tuesday the 4: of Octr last we went to Tunbridge; Mr Thrale had looked particularly ill for two or three Days . . but he was Cupped by Dr Heberden's advice and the Symptoms went off . ...59

Up to this point Mrs Thrale's attitude to Heberden seems to be neutral-but in the New Year her tone suddenly changed:

5: January $1780 \ldots$ Heberden and I do not hit it off at all-he is so cold \& dry, and seems to have so little notion of Who I am as I say sometimes in Joke, that I can hardly bear him: I am not used to People that do not worship me, \& of course grow very fastidious in my desire of Flattery. March Another Stroke of the Apoplexy or Palsy or some dreadful Thing! poor Mr. Thrale! and with such a Desire of Life too-how it shocks one! but Sir Richard Jebb ${ }^{60}$ has saved his Life; Heberden left us in our Distresses very ungenteely . . ..61

Mrs Thrale was engagingly frank in describing her antipathy to Heberden; he, in turn, may well have been offended by her evident desire to hold the centre of the stage, when her husband's life was in the balance.

${ }^{54}$ Ibid., letter 620 .

55 Ibid., letter 629 .

${ }^{56}$ William Bromfield (1712-92), surgeon; he lectured on surgery and anatomy and helped to found the Lock Hospital.

57 Richard Huck (1720-85)) added Saunders to his name after marrying an heiress; MD of Aberdeen; he settled in London, became a Licentiate of the RCP and was later FRCP by special grace.

58 William Seward (1747-99), anecdotist and FRS.

${ }^{59}$ K. C. Balderston (editor), Thraliana - the diary of Mrs. Hester Lynch Thrale 1776-1809, Oxford, Clarendon Press, 1942, pp. 389, 391, 399, 409.

60 Jebb (1729-87)) was an MD of Aberdeen and was made FRCP by special grace. He was FRS and FSA and was physician extra-ordinary to George III. According to Munk, he was an eccentric with a wild look and an impetuous manner. (W. Munk, Roll of Fellows of the Royal College of Physicians, London, Royal College of Physicians, vol. 2, 1878, pp. 309-311.)

${ }^{61}$ Balderston, op. cit., note 59 above, pp. 416, 432. 


\section{William Heberden the elder (1710-1801)}

Johnson consulted many physicians during the course of his life; but he had his favourites, one of whom was Dr Thomas Lawrence, Registrar and later President of the RCP. Lawrence died early in 1783, and it must have been at that point that Johnson decided to ask Heberden to attend him, should the need arise. The moment came sooner than Johnson expected and in his famous letter to his friend the Rev. Dr Taylor, who was in London, he sought Heberden's advice for the first time:

June 17,1783

Dear Sir, It has pleased GOD, by a paralytic stroke in the night to deprive me of speech. I am very desirous of Dr. Heberden's assistance, as I think my case is not past remedy. Let me see you as soon as it is possible. Bring Dr. Heberden with you if you can ....

I think that by a speedy application of stimulants much may be done. I question if a vomit, vigorous and rough, would not rouse the organs of speech to action. As it is too early to send, I will try to recollect what I can, that can be suspected to have brought on this dreadful distress.

I have been accustomed to bleed frequently for an asthmatic complaint; but have forborne for some time by Dr. Pepys's ${ }^{62}$ persuasion, who perceived my legs beginning to swell. I sometimes alleviate a painful, or more properly an oppressive, constriction of my chest by opiates; and have lately taken opium frequently, but the last, or two last times, in smaller quantities. My largest dose is three grains, and last night I took two. You will suggest these things (and they are all that I can call to mind) to Dr. Heberden. ${ }^{63}$

Heberden was at Windsor, where he had bought a house the previous year for his retirement; but, despite some delay in his arrival, Johnson was able to tell Boswell on 3 July: “. . They [Heberden and Brocklesby $]^{64}$ came, and gave the directions which the disease required, and from that time I have been continually improving in articulation. I can now speak, but the nerves are weak, and I cannot continue discourse long; but strength, I hope, will return. The physicians consider me as cured. I was last Sunday at Church ....."65

Johnson's toughness and presence of mind is apparent in his letter to Taylor; despite his distress, he was entirely lucid and practical; he gave the maximum amount of information to help his "new" physician, and remembered to include some suggestions for his own treatment. By the following January, Johnson's old enemies, asthma and dropsy, had returned to afflict him, and in February he wrote to Heberden:

Dear Sir, When you favoured me with your last visit, you left me full of cheerfulness and hope. But my Distemper prevails, and my hopes sink, and dejection oppresses me. I entreat you to come again to me and tell me if any hope of amendment remains and by what medicines or methods it may be promoted. Let me see you, dear Sir, as soon you can. I am, Sir, Your most obliged and most humble servant, Sam: Johnson ${ }^{66}$

During the next few months his condition gradually improved and he decided to travel to the country. In August, he wrote: "My appetite is still good, which I know is

\footnotetext{
${ }^{62}$ Sir Lucas Pepys (1742-1830) studied medicine at Edinburgh. Fellow and later President of the RCP. Physician-in-ordinary to George III.

${ }^{63}$ Boswell, op. cit., note 51 above, p. 1240.

${ }^{64}$ Richard Brocklesby (1722-97) studied medicine at Edinburgh and Leiden, where he took his MD. He was elected FRCP and took an active part in the affairs of the College. He was an army physician during the Seven Years War and then settled in Norfolk Street, not far from Heberden's house.

${ }^{65}$ Boswell, op. cit., note 51 above, p. 1243.

66 Chapman, op. cit., note 53 above, letter 930.
} 


\section{Ernest Heberden}

dear Dr. Heberden's criterion of the vis vitae."67 But the trip did nothing to improve his condition and when he wrote to Heberden in October "to give some account of myself", he ended his letter: "The summer has passed without giving me any strength. My appetite is, I think, less keen than it was, but not so abated as that its decline can be observed by anyone but myself. Be pleased to think on me sometimes."68

When Johnson died in December, Brocklesby conveyed the news to Boswell in Edinburgh, and in the course of a lengthy letter wrote:

The last time all the Drs. consulted together when we entered his room he began thus from Swift, 'The Doctors tender of their Fame, wisely on me lay all the blame, We own indeed his case was nice, but He would never take advice, Had he been ruld, for what appears He might have livd these twenty Years, for when we opend him we found his vital parts were sound.'

'Now' says he, 'Brocklesby will lay my death to disobedience and my taking lately $\mathbf{4}$ times as much Squills as he advisd and Dr. Heberden will say, I disturbed Natures operation in the outlet she made spontaneously in one leg, when I maugre all advice punctured myself the other leg which never ouzed any, but stopped by not ouzing the current of tother.' ... The good Man had his wishes answered for at last he dyed possessed of his mind, in as full vigour as ever and reconciled to the final close. ${ }^{69}$

Johnson's light-hearted prediction of how his doctors would excuse themselves for his death contained a truth that must surely have applied to many physicians anxious to exonerate themselves from feelings of guilt or embarrassment when their efforts to save a patient's life proved unavailing.

A somewhat unusual variant on the custom of seeking medical advice by post was employed by Benjamin Franklin, whom Heberden had come to know in the late 1750s, when he was agent in England for the American colonies. In the autumn of 1782, he began to suffer from stones in the bladder; when the trouble persisted, he composed an account of his symptoms and had the document circulated to no less than five doctors, Heberden included, who were asked to advise on the best treatment. Franklin's action was prompted by the fact that for some time he had been in Paris as first American minister to the Court of Versailles, and he would not, under the circumstances, have been persona grata in England. When Heberden received a copy of the circular, it was accompanied by a document giving the joint views of three of the other doctors-Dr. William Watson, ${ }^{70}$ the surgeon John Hunter and (confusingly) a Dr John Hunter, who was not related to his more famous namesake. A covering letter from Dr Hunter was enclosed and Heberden replied:

Windsor 18 Jul 1785

Dear Sir, I was this morning favoured with your letter accompanied with a case and consultation upon it; all which I have considered and do not find that there is anything left for me to say, unless that I entirely agree with you, Dr. Watson and Mr. Hunter in recommending to the gentleman not to think of an operation at such an advanced age, but to trust wholly to the

\footnotetext{
${ }^{67}$ Boswell, op. cit., note 51 above, p. 1339.

${ }^{68}$ Chapman, op. cit., note 53 above, letter 1022.

69 Marshall Waingrow (editor), Correspondence and other papers of James Boswell relating to the making of the Life of Johnson, New Haven, Conn., Yale University Press, 1969-, vol. 2, p. 34.

70 William Watson (1715-87), FRS; awarded the Society's Copley medal for his researches into electricity. Created MD by the Universities of Halle and Wittenberg; Physician to the Foundling Hospital; elected FRCP 1784.
} 


\section{William Heberden the elder (1710-1801)}

Lixivium, ${ }^{71}$ if he can bear it. I suppose he could find no difficulty in taking a teaspoonful night and morning; and if he could take two it would be more desirable. Exercise can hardly be wanted for health at the age of 79; it is high time to lay aside all business which would oblige a man to go out, and use much motion: I wish therefore your patient would confine himself wholly to his house and garden, and avoid all riding in a Carriage. If this cannot wholly be avoided, and a fit should be brought on by the motion, or by any other cause, the best relief will be afforded by the Anodyne Clyster; and if his body be tolerably regular as to stools, I know of nothing further that his complaints require.

Wm. Heberden ${ }^{72}$

Almost everything in this letter is consistent with the views that Heberden expressed elsewhere on the management of "the stone"; but it is difficult to believe that he had much faith in the Lixivium or in any other reputed dissolvent, in the light of his remarks in the Commentaries. ${ }^{73}$

Although Heberden had been offered a court appointment in 1761 as physician-inordinary to Queen Charlotte, he had refused it politely but firmly, on the grounds "that it might interfere with those connexions in life that he had now formed." 74 When the court was at Windsor, twenty-three miles away, even a brief attendance on the queen would have removed him from London for at least a whole day; besides the time spent on the road, protocol could make attendance on royal patients time-consuming and frustrating. Apart from these considerations, Heberden's ample income and assured reputation diminished what other men might have regarded as the attractions of such an appointment. Fortunately, the refusal caused no offence and the friendly relations which Heberden continued to enjoy with the court were later symbolized by his choice of summer residence-a house situated next to Windsor Castle.

George III suffered his first serious derangement in the summer of 1788, and when after a brief respite he relapsed in November, Heberden was called in at the request of his former pupil, Sir George Baker. ${ }^{75}$ Fanny Burney gave a graphic description of the night when the king kept up a rambling monologue for several hours on end, and quoted some of his words:

'I am nervous' he cried; 'I am not ill, but I am nervous: if you would know what is the matter with me, I am nervous. But I love you both very well; if you would tell me the truth: I love Dr. Heberden best, for he has not told me a lie: Sir George has told me a lie-a white lie, he says, but I hate a white lie! If you will tell me a lie, let it be a black lie!?76

${ }^{71}$ Blackrie's Lixivium was a mixture of potash and quicklime dissolved in water. Alexander Blackrie had written A disquisition on medicines that dissolve the stone (London, 1766), which was widely commended, and Heberden was one of the subscribers to its publication.

72 Quoted in G. W. Corner and W. E. Goodwin, 'Benjamin Franklin's bladder stone', J. Hist. Med., 1953, 8: $359-377$, see p. 367.

73 See Commentaries, ch. 16.

74 Macmichael, op. cit., note 12 above, p. 178.

75 The king's "mania" has been analysed in detail by Ida Macalpine and Richard Hunter, George III and the mad-business, London, Penguin Press, 1969. Despite the early consultation, Heberden played only a minor role in the king's management.

Sir George Baker (1722-1809) was at King's College, Cambridge, and became Fellow and President of the RCP. He demonstrated that Devonshire colic was caused by the leaden vessels used in cider-making (H. A. Waldron, 'The Devonshire colic', J. Hist. Med., 1970, 25: 383-403; R. M. S. McConaghey, 'Sir George Baker and the Devonshire colic', Med. Hist., 1967, 11: 345-360.) Baker became one of the royal physicians after Heberden had introduced him to the court.

${ }_{76}$ Barrett, op. cit., note 48 above, vol. 2, p. 136. 


\section{Ernest Heberden}

Amongst other patients seen by Heberden during his years of semi-retirement was Josiah Wedgwood, who came to consult him about his "rheumatic headaches"; evidently he was satisfied with the advice received, and soon afterwards wrote to inform Heberden that the prescribed "blister" had relieved the headaches and that he intended to take the other part of the prescription - a holiday - as soon as the Portland Vase was completed. ${ }^{77}$

Probably the last patient in Heberden's long career was Sir Joshua Reynolds, whom he visited in 1792. Reynolds had been struck down by a disease of the liver, and, according to his close friend Edmund Malone, the physicians who first attended him were "extremely negligent and failed to exert themselves." was already past help, Heberden was called in to advise-a tribute perhaps to his continuing reputation at the advanced age of eighty-two.

A few weeks before the death of Dr Johnson, Heberden wrote once again to Philip Yorke, Earl of Hardwicke:

Windsor 2 Oct 1784

My Lord, I this morning received the honour of your Lordsp's letter and if this should be the last journey to Bath, I hope it will be owing to receiving so much benefit as to have no further occasion to make it another visit. If I had felt no solicitude about your Lordsp's health, I must have lost all memory of the many agreeable parties in which we have often met when we were much younger in the University. Our friend Mr. Wray ${ }^{79}$ was quite worn out and died truly of old age; this consideration ought to make his surviving friends easy under his loss; and if it have not yet had its due weight with me, your Lp., to whom his just taste and agreeable manners \& virtuous principles were so well known, will, I doubt not, excuse my weakness. I must hope that in this, as is seen in many other instances, Time will at last do what reason should have done at first \& made me more thankful that I have had such a friend than disposed to repine because I have lost him. I am, with great respect, my Lord...W. Heberden ${ }^{80}$

Heberden's sorrowful reaction to the death of one of his oldest Cambridge friends reminds us that those who died "truly of old age" were in a minority; the deaths of children and people in the prime of life must have been depressing to all but the most callous physicians. Heberden had had his full share of personal bereavements ${ }^{81}$ and took the view that the best way to recover one's equanimity was to keep fully occupied - a view expressed in his letter to Thomas Percival quoted below. Percival, a unitarian, was one of the first students to be enrolled at the Academy for dissenters in his home town of Warrington. He studied medicine in Edinburgh and spent a year in London, during which time he was elected FRS. After setting up his practice in Manchester, he did much to improve public health and conditions in factories. When preparing his book Medical ethics, he sent Heberden a draft of the work, and in the course of a letter acknowledging it, Heberden wrote:

... Your being able to resume the work you had in hand, makes me hope that your good principles, with the aid of time, have greatly recovered your mind from what you must have

${ }^{77}$ E. Posner, 'Josiah Wedgwood's doctors', Pharmaceutical Historian, 1973, 3:1.

${ }^{78}$ Historical Manuscripts Commission, MSS of the Earl of Charlemont, letter 179.

79 Daniel Wray (1701-83) took his degrees at Queens' College, Cambridge, and lived there for several years; FRS and FSA. He was patronized by the Hardwicke family and was a Trustee of the British Museum.

${ }^{80}$ BM Add. MS $35623 \mathrm{fb}$.

${ }^{81}$ His first wife and her first child both died; he and his second wife lost three children in infancy, one son aged sixteen and another in his twenties. 


\section{William Heberden the elder (1710-1801)}

suffered on occasion of the great loss in your family; and your attention in the further prosecution of it, will powerfully assist in perfectly restoring your tranquillity. ${ }^{82}$

Later in the same letter, Heberden sets out his attitude towards retirement:

... I have entered my 85 th year; and when I retired, a few years ago, from the practice of physic, I trust it was not from a wish to be idle, which no man capable of being usefully employed has a right to be, but because I was willing to give over, before my presence of thought, judgement and recollection were so impaired, that I could not do justice to my patients. It is more desirable for a man to do this a little too soon, than a little too late; for the chief danger is on the side of not doing it soon enough.

Up to this point, I have said virtually nothing about Heberden's poorer patients, apart from suggesting that he may have treated the servants and retainers of the well-to-do. The information is far too scanty to suggest what proportion of his time he gave to caring for the less fortunate, but ordinary wage-earners definitely received his attentions. He could have seen them in any one of at least four locations: in his own consulting room, in the patient's home, in a coffee house (a popular venue for consultations), or in a hospital. As he held no hospital appointment, any visit he made would probably have been at the invitation of the resident physician; one visit is described in the Commentaries (ch. 49) and begins dramatically: "26th June 1764, in St Thomas's Hospital I saw a woman of six-and-thirty years of age motionless with a fit of the catalepsy." But it would be wrong to infer from this that hospital visits were frequent; it is more likely that Heberden was invited to come and see the woman because her case was so unusual.

Another patient, who suffered, amongst other things, from night-blindness, was employed on ships moored in the Thames. It is clear that Heberden visited him several times during his final illness. ${ }^{83}$ In discussing jaundice, Heberden referred to "people of the middling or lower rank" who "are not hindered by it from doing all the common business of life, where no great exertion of strength is required." 84

Further clues to the scale of his practice can be found in his Index historiae morborum ${ }^{85}$ where he recorded in Latin, under the appropriate heading, "such facts as tended to throw any light upon the history of a disease, or the effects of a remedy."86 Many of these entries are followed by a serial number, the highest of which indicates that by the end of his career he had seen at least 6,500 cases, many of them requiring several visits. This is not a large total for a practice lasting so many years; but if the serial numbers were simply used for accounting purposes, the poor (non-paying) patients would be omitted from the series and the real total increased.

Although we know the identity of many more patients than the few mentioned in this article, their cases tell us little of relevance. Fortunately, there are a number of passages in Heberden's works in which, though naming no names, he adds to our understanding

\footnotetext{
82 Thomas Percival, Medical ethics, Manchester, 1803, p. 202. Details of Percival's career are given in J. V. Pickstone and S. V. F. Butler, 'The politics of medicine in Manchester 1788-92', Med. Hist., 1984, 28: $227-249$.

${ }^{83}$ Commentaries, p. 334.

84 Med. Trans., 1772, 2: 142.

${ }^{85} \mathrm{MS}$ in library of RCP.

86 Commentaries, preface.
} 


\section{Ernest Heberden}

of his attitude towards patients in general as well as towards individuals. The opening paragraph of the first chapter of the Commentaries 'On diet' is a good example:

Many physicians appear to be too strict and particular in the rules of diet and regimen, which they deliver as proper to be observed by all who are solicitous either to preserve or recover their health. The too anxious attention to these rules hath often hurt those who are well, and added unnecessarily to the distresses of the sick. The common experience of mankind will sufficiently acquaint anyone with the sorts of food which are wholesome to the generality of men; and his own experience will teach him which of these agrees best with his particular constitution....

And later in the same chapter we read:

There is scarcely any distemper, in every stage of which it may not be safely left to the patient's own choice, if he be perfectly in his senses, whether he will sit up, or keep his bed. His strength and his ease are chiefly to be attended to in settling this point; and who can tell so well as himself, what his ease requires, and what his strength will bear?

Apart from the remarkably unstarchy attitude revealed by these two extracts, there is another point of interest in the reference to "those who are well"-a clear pointer to Heberden's interest in preventive medicine. This can be illustrated by his 'Remarks on the pump-water of London', ${ }^{87}$ where he warned against the dangers of contamination and recommended that the water should not be drunk until it had been either distilled or filtered. Another example was his advocacy of inoculation against smallpox-an operation he performed frequently, following the Suttons' method. ${ }^{88}$ The dangers of "the abuse of spirituous liquors" were referred to several times, and in ch. 50 of the Commentaries he remarked: "Men are more commonly affected with scirrhous livers than women, because they are more given to intemperate drinking, which is the principal cause of this disorder." 89

Heberden's concern for patients in distress is most clearly conveyed in his discussion of depression, ${ }^{90}$ which "appears to be a misery much harder to be borne than most other human evils, and makes every blessing tasteless and unenjoyable." ${ }^{.11}$ In the same chapter he stated his view of the interaction between body and mind:

Our great ignorance of the connexion and sympathies of body and mind, and also of the animal powers, which are exerted in a manner not to be explained by the common laws of inanimate matter, makes a great difficulty in the history of all distempers, and particularly of this. For hypochondriac and hysteric complaints seem to belong wholly to these unknown parts of the human composition; the body itself, as far as our senses are able to discern, seeming to have all its integrity and perfection in those who have long and greatly suffered by these disorders. But there is hardly any part of the body which does not sometimes appear to be deeply injured by the influence of great dejection of spirits .....92

${ }^{87}$ Med. Trans., 1768, 1:1.

${ }^{88}$ Heberden described "the manner of inoculating" in a two-part pamphlet produced in collaboration with Benjamin Franklin, with a view to encouraging the practice of inoculation in America. The first part was written by Franklin and the "plain instructions" by Heberden. The complete pamphlet was entitled Some account of the success of the inoculation for the small pox in England and America, together with plain instructions by which any person may be enabled to perform the operation and conduct the patient through the distemper, London, W. Strahan, 1759. See also, David van Zwanenberg, 'The Suttons and the business of inoculation', Med. Hist., 1978, 22: 71-82.

${ }^{89}$ Commentaries, p. 253.

90 Ibid., ch. 49, entitled 'Hypochondriacal and hysterical affections'.

91 Ibid., p. 224.

92 Ibid., p. 225. 
Euthanasia (in the original meaning of the word) received Heberden's warm support:

.. .even in hopeless cases in which the dying person is harrassed by unspeakable inquietude, he may be lulled into some composure and without dying at all sooner may be enabled to die more easily. Lord Verulam ${ }^{93}$ blames physicians for not making the euthanasia a part of their studies and surely though the recovery of the patient be the grand aim of their profession, yet where that cannot be attained, they should try to disarm death of some of its terrors and if they cannot make him quit his prey, and the life must be lost, they may still prevail to have it taken away in the most merciful manner.94

The quotations from other writers suggest that they usually trusted Heberden's judgement and liked him as a person. Because they were all aware of the baffling nature of many diseases, they had no exaggerated expectations of cures and were on the whole tolerant of a doctor's failures; if Heberden was occasionally criticized for overoptimism, this was generally the penalty for attempting to keep the patient in a cheerful frame of mind.

From his own letters and other works we can see that he viewed each patient from two angles: as an individual who must be treated with all the skill and wisdom he could command; and as a source of additional knowledge and experience, to be recorded and analysed for the benefit of patients in the future. The immediate benefits of this approach were restricted by the limitations of his time; but he was still able to bring to his London practice qualities of mind and heart that caused Dr Wells to say of him: "No other person, I believe, ... has ever exercised the art of medicine with the same dignity or has contributed so much to raise it in the estimation of mankind." 95

${ }^{93}$ Francis Bacon (1561-1626).

94 Commentaries, ch. 51, 'Inflammation of the bowels', p. 272.

${ }^{95}$ See letter from William Charles Wells to Lord Kenyon, July 1799, quoted in T. J. Pettigrew, 'A biographical memoir of Dr W. Heberden', Medical portrait gallery, London, 1839. 